\title{
PRINCIPAL BIBLICAL AND POST-BIBLICAL CHARACTERS IN THE QUR'ĀN
}

For Qur'ānic references, please see the Index to the Qur'ān.

Aaron-Brother of Moses, called on by God to help Moses in his prophetic mission and his confrontation with Pharaoh.

Abraham - Father of Isaac and Ishmael, monotheist by natural observation. Confronts his idolatrous people and is persecuted, builds a house of God with Ishmael.

Adam-First human, described as a "vicegerent" (khalīfa). Disobeys God by eating from, or approaching, the forbidden tree in paradise.

Alexander the Great-Named "the possessor of two horns" (Dhū 1-Qarnayn) in the Qur'ann. Travels to the ends of the earth.

David -Described like Adam as a "vicegerent" (khalī $f a)$, noted in the Qur'ān for his praise of God and knowledge. Kills Goliath.

Elijah-Briefly mentioned in the Qur'ān for his rejection of the worship of Baal.

Haman - Appears as an assistant to Pharaoh in Egypt, commanded to build a tower to heaven.

Iblis - The devil as cosmic adversary of God. The Qur'ān names the devil instead Satan when he appears as the tempter of humans.

Isaac - Son of Abraham whose miraculous birth is announced on several occasions. Perhaps the son of Abraham who was to be sacrificed before he is redeemed.

Ishmael — Builds a house of God with his father Abraham. Described as "true to his promise." 
Jacob-Father of Joseph (and other sons) who has prophetic knowledge of Joseph's fate.

Jesus - Son of Mary and named al-masīh ("Christ"). Distinguished by his miraculous birth, the miracles which he accomplishes (even in childhood), and his ascension to heaven after his life.

$J o b$ - Mentioned briefly in the Qur'ān for his prayer. Commanded to reprimand his wife.

John - Son of Zechariah, born in his parents' old age. Given judgment while still a child, said to confirm the word of God.

Jonah-A prophet who is said to have "gone off angry" and ends up in the belly of a fish, for which reason he is named "man of the fish" (dhi l-nün) Joseph-Son of Jacob who is enslaved and taken to Egypt where he is first imprisoned. Later becomes a powerful figure and receives his family.

Lot-Revered as a prophet in the Qur' ān and closely connected to Abraham. Condemns his people for their deviant ways.

Mary - Mother of Jesus, praised in the Qur' ān for her purity and faithfulness. Moses - Prophet who confronts Pharaoh, speaks directly with God, and receives a divine revelation (al-tawrät).

Pharaoh/Fir'awn -Name (not title) of the Egyptian ruler in the time of Moses who considers himself a god but meets his demise.

Queen of Sheba-A pagan queen who visits Solomon and comes to believe in God.

Sarah —Named "wife of Abraham" in the Qur' ān, remembered for her incredulous reaction to the annunciation of a son (Isaac) in her old age.

Saul—Referred to as Țālūt, a king before David who leads Israel to war.

Solomon - Remembered for his knowledge and his miraculous authority over natural and supernatural beings, converts the Queen of Sheba to belief in God.

Sons of Adam - While their names are not given the Qur'ān alludes to Cain's killing of Abel.

Zechariah - Father of John, receives an angelic annunciation of his son's birth after imploring God. 
THE QUR'ĀN AND THE BIBLE 
This page intentionally left blank 